\title{
REVIEW
}

\section{PATHOLOGICAL GAMBLING IN WOMEN: A REVIEW}

\author{
Silvia Saboia Martins, Daniela S. S. Lobo, Hermano Tavares and Valentim Gentil
}

RHCFAP/3099

MARTINS SS et al. - Pathological gambling in women: a review. Rev. Hosp. Clín. Fac. Med. S. Paulo 57(5):235-242, 2002.

Pathological gambling was only recently recognized as a psychiatric disorder (DSM-III, APA, 1980). Most studies of pathological gambling include only male subjects. Despite the paucity of information, it is likely that at least one-third of pathological gamblers are women. The objective of this article is to review clinical and epidemiological characteristics of female gamblers as compared to their male counterparts. MEDLINE and PsycINFO were searched for investigational studies and reviews of the past 10 years on clinical (sociodemographic, course and progression, psychiatric comorbidities, genetics, and personality) and epidemiological aspects of female gamblers. Other relevant articles were also selected from reference lists. It is concluded that the current literature indicates some common characteristics in female and male gamblers, but it also indicates the possibility that each gender may carry etiopathogenic differences that when better understood should lead to improved treatment and prevention strategies.

DESCRIPTORS: Pathological gambling. Female gender. Epidemiology. Clinical characteristics. Genetics. Personality.

\section{INTRODUCTION}

Pathological gambling (PG) was only recently officially recognized as a psychiatric disorder after its inclusion in DSM-III ${ }^{1}$. Prevalence studies in North America show rates of $1 \%$ to $4 \%$ of the general population ${ }^{2-4}$. There are no epidemiological data about PG in Brazil. Del Porto ${ }^{5}$ raises the possibility of an increase of PG in our population because of the great popularity of computerized games. When considering legalization, opening, and investment in casinos in a new place (i.e. Brazil), similar investments must also be considered in prevention of PG and treatment of new gamblers and their families who will possibly be affected by the easier access to gambling venues $^{6-9}$. Room, Turner, and Ialomiteanu ${ }^{10}$ observed the impact of the opening of a casino in Niagara Falls (Canada), showing that gambling activity increased in the local population, and consequently more gambling-related problems occurred. Bingo, which has been legalized in Brazil, is seen by the local population as a safe form of leisure and may already have increased gambling-related problems, especially in women ${ }^{11}$.

In the last few years there has been an increase in the number of women with PG, similar to what has been observed regarding alcohol and drug addiction $^{12,13}$. Drug abuse and addiction, and particularly PG have been associated with multiple factors, such as sociocultural background ${ }^{14,15}$, psychiatric symptomatology ${ }^{16}$, and personality ${ }^{17}$.

From the Department of Psychiatry, Hospital das Clínicas, Faculty of Medicine, University of São Paulo and University of Calgary, Canada.
Ettorre $^{18}$ affirms that health professionals that deal with addicts tend to ignore the particular needs of female patients, which also occurs with female gamblers. PG and chemical addiction share similarities, which include difficulty in controlling the impulse to gamble/abuse substances and the persistence in gambling/using substances despite negative consequences ${ }^{9,16,19}$.

Mark and Lesieur ${ }^{20}$ emphasize the need for more research focused on female gamblers in order to develop specific prevention and treatment strategies. For example, there are reports that women who seek treatment for emotional and relationship problems are rarely questioned about their gambling habits, and consequently they do not receive adequate treatment ${ }^{21}$. Blume and Lesieur ${ }^{22}$ interviewed a sample of 50 female gamblers who were Gamblers Anonymous (G.A.) 
members and verified that $29(58 \%)$ had already sought help from a mental health professional. Of these, 17 $(34 \%)$ did not mention that they were gamblers, $8(16 \%)$ were considered to have a minor gambling problem, and only $4(8 \%)$ were sent by their therapists to G.A.

\section{METHODS}

MEDLINE and PsycINFO were searched for PG studies and reviews of the past 10 years with special emphasis on clinical (sociodemographic, course and progression, psychiatric comorbidities, genetics, and personality) and epidemiological aspects of female gamblers. Other relevant articles published previously, were also selected from reference lists.

\section{EPIDEMIOLOGY}

Most PG studies are conducted with male subjects, despite the fact that one-third of PG are women ${ }^{20,23,24}$. Lesieur $^{21}$ showed that only $2 \%$ of New Jersey's G.A. members were women, and only $14 \%$ of the calls to "800 Gambler" were done by female gamblers. Volberg and Steadman ${ }^{25}$ verified that only $7 \%$ of gamblers in PG treatment programs in New York (USA) were women. A clinical sample in our country found a male-female ratio of $1: 1^{11}$. This ratio is higher than the observed in treatment program and G.A. group studies (from 7:1 to $10: 1)^{6,26}$. Yet, PG prevalence studies in the general population show a male-female ratio of $2: 1$ to $3: 1^{2,3,12,23,27}$.

Ladouceur, Dubé, and Bujold ${ }^{28}$ analyzed a sample of 1471 students (mean age: 18 years) and found that $5.7 \%$ of males and $0.6 \%$ of females had a diagnosis of PG (male/female ratio of 9.5:1). In another sample of 1771 university students (mean age: 22.3 years)
Lesieur et al. ${ }^{29}$ found a male/female ratio of $4: 1$, which reinforces the hypothesis that this problem appears later in women than in men.

\section{SOCIO-DEMOGRAPHIC CHARACTERISTICS}

In the few studies about female gamblers, noteworthy is the description by Strachan and Custer $^{30}$ of 52 female gamblers of the Las Vegas G.A. in 1989. They identified the typical gambler as Caucasian (83\%), 30-49 years-old $(76 \%)$, married $(67 \%)$, with children $(75 \%)$, with a high school education (74\%), and a video poker player (90\%). Problems related to gambling were suicide attempts $(23 \%)$, alcoholism (10\%), illicit drug addiction (23\%), and licit drug addiction (15\%). The authors reported that $10 \%$ of the women engaged in prostitution solely to obtain money to gamble. No comparison with male gamblers was done ${ }^{30}$. Tavares et al. ${ }^{11}$ described 39 female gamblers and obtained similar results, except for marital status (the majority of women, 59\%, were single), and a preference for bingo $(54 \%)$. In this study, there were no significant sociodemographic differences between male and female subjects.

\section{COURSE AND EVOLUTION}

Some authors suggest that PG progression is faster in women ${ }^{11,16,31,32}$. The accelerated development of addiction in females, the so-called "telescoping effect" (T.E.), was first described in alcoholism by Lisansky ${ }^{33}$ and confirmed by Piazza et al. ${ }^{34}$, as well as observed in opioid addiction by Anglin et al. ${ }^{35}$. Other authors have also described T.E. in female alcoholics and opioid ad$\operatorname{dicts}^{36-38}$.

Many studies showed that T.E. in alcoholism occurs in the interval between the age at which they first ex- perienced alcohol-related problems and the time they sought treatment ${ }^{34,39,40}$. Lewis et al. ${ }^{41}$ described that women start to drink later than men but develop problems in the first 2 years of alcohol use.

Randall et al. ${ }^{42}$ amplified T.E.'s definition, showing that it occurs in female alcoholics in 2 progressive intervals: in the period between the beginning of alcohol regular use and the first alcohol-related problems and in the interval between loss of control of drinking and the worst drinking problems. In female gamblers, T.E. occurs in 2 periods: in the interval between gambling intensification and the first gambling-related problems and between these first problems and the time they sought treatment. ${ }^{11}$

\section{PSYCHIATRIC COMORBIDITY}

Male gamblers have high lifetime comorbidity with affective disorders $(21 \% \text { to } 60 \%)^{16,43}$, and with drug addiction $(25 \% \text { to } 65 \%)^{16,44}$. Mark and Lesieur $^{20}$ suggest that these comorbidities may also occur in women. Some authors state that women gamble more frequently as a means to escape from problems or alleviate dysphoria $^{27,29}$.

\section{GENETICS}

A genetic inheritance mode for drug addicts and PG has not yet been established ${ }^{45}$. Eisen et al. ${ }^{46}$ analyzed 3359 twin pairs and concluded that familial factors (both genetic and environmental) explained $56 \%$ to $62 \%$ of the occurrence of $\mathrm{PG}$, with significant evidence of PG familial aggregation. Mono (MZ) and dizygotic (DZ) PG twins had a lifetime prevalence of $22.6 \%$ and $9.8 \%$, respectively ${ }^{46}$, which are significantly higher than the prevalence in the general population ${ }^{2-4}$. 
Some authors suggest that gamblers become addicted to an euphoric sensation, similar to that elicited by drugs $^{47}$. Therefore, the concept of PG is being changed towards that of an addiction similar to alcohol and drug addiction $^{48-50}$. Corroborating this is the fact that gamblers have high rates of comorbidity with alcohol and drug addiction. For instance, $19 \%$ to $50 \%$ of gamblers in clinical samples had a previous history of either alcohol abuse or drug addiction ${ }^{16,44}$.

Slutske et al. ${ }^{51}$ investigated the familial aggregation of PG and alcohol dependence $(\mathrm{AD})$ to examine how much rates of $A D$ were increased among MZ and DZ PG twins. A comparison of co-aggregation patterns among PG and AD revealed whether there was a common genetic and environmental vulnerability between PG and $\mathrm{AD}$. Even though there were no significant differences between rates of AD among gamblers' siblings, MZ presented higher $\mathrm{AD}$ rates compared to DZ, which suggests that genetic factors may explain familial co-aggregation. The authors verified that $\mathrm{AD}$ risk contributes for significant share of genetic and environmental risk for PG. PG shared as much as $12 \%$ to $20 \%^{51}$ of risk factors with $\mathrm{AD}$. These data suggest a common genetic vulnerability for $\mathrm{PG}$ and $\mathrm{AD}$, as well as a specific genetic vulnerability for PG.

Unfortunately, all studies above had only male subjects; therefore, these findings may not apply to female gamblers. Perez de Castro et al. ${ }^{52}$ found a more significant genetic association of PG and the DRD4 gene in female gamblers. Comings ${ }^{53}$ found an association of PG and allele D2A1 of the DRD2 gene that was correlated with gambling severity. Regarding gender, there was a very significant difference in the presence of D2A1, despite the small female sample $(n=17): 83.3 \%$ of the non-depressed female gamblers had the allele, against only $9.1 \%$ of depressed female gamblers. Therefore, it is possible that non-depressed women gambled in search of risk and excitement, thus illustrating the importance of "reasons to gamble" in the molecular biology of $\mathrm{PG}^{53}$. According to Comings ${ }^{53}$, DRD1, DRD3, and DRD4 genes were also associated with PG, but here no gender difference was investigated.

Ibañez et al. ${ }^{54}$ analyzed MAO-A and MAO-B gene polymorphisms among 47 male and 21 female PG, compared to normal controls, and found a possible association between allele B of MAO-A in male gamblers, which was not confirmed for female gamblers.

\section{PERSONALITY}

Few studies analyze the impact of gender on personality characteristics of individuals with the diagnosis of substance abuse or addiction ${ }^{55,56}$. According to Mark and Lesieur ${ }^{20}$, all studies about gamblers' personality characteristics were performed in predominantly male subjects.

Roy et al. ${ }^{57}$ compared 19 male gamblers to normal controls and found higher neuroticism and psychoticism in gamblers using Eysenck's model ${ }^{58}$. Similar data had been previously obtained by Blaszczynski et al. ${ }^{59}$. In both studies there was no comparison with a female sample. Steel and Blaszczynski ${ }^{17}$ used Eysenck's ${ }^{60}$ impulsivity scale to analyze personality characteristics of 82 gamblers, of whom only $22(27 \%)$ were women. They observed high impulsivity in gamblers compared to normative data; however, they did not compare the male and female subgroups.

Mendlowicz et al. ${ }^{61}$ studied personality characteristics of normal volunteers and showed that women had higher scores of Cloninger's ${ }^{62-64}$ "Reward Dependence" factor compared to men. Studies in normal populations in Japan also obtained the same results ${ }^{65,66}$. Meszaros et al. ${ }^{67}$ found the "Harm Avoidance" factor (Cloninger's model $\left.{ }^{(2-64}\right)$ higher in female alcoholics compared to males. Pomerleau et al. ${ }^{68}$ found the same in nicotine addicts. In contrast to the studies with normal volunteers, there were no gender differences regarding "Reward Dependence" factor. There still have not been studies published that investigate gender personality differences in PG, which deserves to be studied.

\section{DISCUSSION}

From the epidemiologic data, we observed that the occurrence of $\mathrm{PG}$ in women is higher than the previously supposed. However, a minority of female gamblers seeks G.A. groups and treatment programs ${ }^{20,25}$. There are no prevalence studies of PG in Brazil, which limits the interpretation of data.

Only recently has gambling become more accessible in Brazil, especially after the legalization of commercial bingo. Culturally, amateur bingo is seen as a means of raising funds for charity. It is possible that this fact may have favored the acceptability of commercial bingo, and therefore, females have more access to gambling activities.

Countries have different legalized gambling venues. There is also evidence that genders differ in relation to the type of game preference ${ }^{69}$ and attitudes towards gambling ${ }^{70}$. However, these studies were not performed in PG subjects. Therefore, as Mark and Lesieur ${ }^{20}$ state, gender susceptibility to PG in relation to cultural aspects and different types of gambling, remains a promising and still unexplored research field.

Regarding sociodemographic characteristics, one important limitation found in the few studies about female 
gamblers is that they were performed in clinical populations ${ }^{11,30}$. Since few female gamblers reach treatment settings, it is possible that the majority of them, who are not being treated, have not been adequately studied. According to Mark and Lesieur ${ }^{20}$, PG studies have not discussed the gender of study subjects or reported and investigated gender-specific results, and most of them were performed in gambling venues frequented predominantly by male gamblers.

It is known that females start gambling later than $\operatorname{men}^{20}$. However, because of T.E., they reach treatment at the same age as men ${ }^{11}$. Since T.E. is a phenomena common to alcohol and drug addiction as well as PG, studies that explore the physiopathology of these conditions could clarify the biologic (genetic and/or hormonal) and sociocultural factors that contribute to this accelerated course in women. Another implication of this finding is that the time for intervention before progression to advanced stages of PG is reduced in females, reinforcing the importance of the development of specific strategies of prevention and treatment for this population ${ }^{45}$.

As yet, there have been no comorbidity psychiatric studies specifically about female gamblers. Study subjects were male-only or predominantly male ${ }^{43,44}$. Future research must investigate the occurrence of psychiatric comorbidity in female gamblers and compare it with male gamblers.
Accordingly, it should not be forgotten that depressive and anxious disorders are more prevalent in females in the general population ${ }^{71}$.

Regarding genetic aspects, the study that investigated familial occurrence of $\mathrm{PG}^{46}$ found significant evidence of PG heritability (environmental and genetic). Another important factor, seen in the study of Slutske et al. ${ }^{51}$ is that as in alcohol addiction ${ }^{72}$, PG presents a specific heritability that is common to alcoholism. This data strengthens the proposal for studying $\mathrm{PG}$ as an addiction. Though there are still only 2 genetic studies with female gamblers ${ }^{52,54}$, both with small sample sizes, Ibañez et al. ${ }^{54}$ suggest that the association between allele $\mathrm{B}$ of MAO$\mathrm{A}$ and PG may be gender-specific, which could imply an etiopathogenic difference between male and female gamblers.

There are no studies comparing personality aspects of male and female gamblers. Though the relationship of gender, PG, substance addiction, and personality may be promising, it is necessary to emphasize that the few studies that explored this field failed to control 2 important areas of bias: variations in sociodemographic background, and prevalence of depressive symptoms ${ }^{17,55-57,67,68}$. Mendlowicz et al. ${ }^{61}$ analyzed normal volunteers and found that occupational status influences "Reward Dependence" and "Cooperativeness". It is also well established that depressive disorders are more prevalent in females ${ }^{71}$ and that the "Harm Avoidance" factor is influenced by depression, which transiently overemphasizes this factor ${ }^{73}$. Since personality aspects play an important role in $\mathrm{PG}^{17}$, it is necessary to study them in female gamblers.

\section{CONCLUSION}

Gender studies are clearly more numerous in substance addictions than in PG. Similarities between these disorders suggest that a better understanding of the relationship between PG and gender is promising. The few studies found in this area indicate that gambling impacts genders in different ways. Gender may carry factors that determine distinct etiopathogenic mechanisms. Although they share the same symptoms, a better understanding of the differences between male and female gamblers may help in developing more efficient strategies of prevention and treatment of PG.

\section{ACKNOWLEDGMENT}

The authors thank Dr. Mônica L. Zilberman for her contribution in text review.

This study was partially supported by FAPESP (The State of São Paulo Research Funding Agency, process 00/ 14215-9).
MARTINS SS e col. - Jogo patológico em mulheres: uma revisão. Rev. Hosp. Clín. Fac. Med. S. Paulo 57(5):235-242, 2002.
Ainda que jogos de azar e os problemas a eles relacionados sejam antigos para a humanidade, o Jogo Patológico, como alteração do comporta- mento humano, somente passou a ser reconhecido oficialmente como transtorno psiquiátrico a partir de sua inclusão na 3a Edição do Manual Diagnós- 
tico e Estatístico de Transtornos Mentais (APA,1980). A maioria dos estudos sobre jogadores patológicos tem como base uma população eminentemente masculina. Entretanto, estima-se que pelo menos um terço dos indivíduos que recebem este diagnóstico sejam mulheres. O objetivo deste estudo foi revisar características clínicas e epidemiológicas de jogadoras comparadas a jogadores. As bases de dados MEDLINE e PsycINFO foram consul- tadas a respeito de estudos sobre Jogo Patológico publicados nos últimos dez anos, com especial enfoque para características clínicas (dados sóciodemográficos, curso e evolução, comorbidade psiquiátrica, genética e personalidade) e epidemiologia. Artigos relevantes publicados anteriormente ao período escolhido de revisão foram selecionados a partir da lista original de referências. Os autores conclu- em que a literatura atual indica que jogadoras e jogadores apresentam semelhanças, mas carreiam possíveis diferenças etiopatogênicas cujo esclarecimento deverá aprimorar as estratégias de tratamento e prevenção.

DESCRITORES: Jogo patológico. Gênero feminino. Epidemiologia. Características clínicas. Genética. Personalidade.

\section{REFERENCES}

1. AMERICAN Psychiatric Association - Diagnostic and Statistical Manual of Mental Disorders. 3rd ed. Washington, DC, 1980.

2. LADOUCEUR R - Prevalence estimates of pathological gambling in Quebec. Can J Psychiatry, 1991; 36: 732-734.
3. SHAFFER HJ, HALL MN \& VANDER-BILT J - Estimating the prevalence of disordered gambling behaviour in the United States and Canada: a research synthesis. Am J Pub Health, 1999; 89 (9),1369-1376. 
4. POTENZA MN, KOSTEN TR \& ROUNSAVILLE BJ - Pathological gambling. J Am Med Assoc, 2001; 286 (2),141-144.

5. DEL PORTO JA - Compulsões e impulsos: cleptomania, jogar compulsivo, comprar compulsivo, compulsões sexuais- In: MIGUEL EC (Ed.)- Transtornos do Espectro ObsessivoCompulsivo: Diagnóstico e Tratamento. Rio de Janeiro, Guanabara Koogan, 1996. p. 109-116.

6. CUSTER RL \& MILT H - When luck runs out. New York, NY, Facts on File Pub, 1985

7. VOLBERG RA - Estimating the prevalence of pathological gambling in the United States. In: EADINGTON WR and CORNELIUS JA (Eds)- Gambling Behaviour and Problem Gambling. Reno, NV, Institute for the Study of Gambling and Commercial Gaming, 1993. p. 365-378.

8. LESTER D - Access to gambling opportunities and compulsive gambling. Int J Addictions, 1994; 29 (12): 1611-1616.

9. TAVARES H, GENTIL V, OLIVEIRA C et al. - Jogadores patológicos, uma revisão: psicopatologia, quadro clínico e tratamento. Rev Psiquiatria Clín, 1999; 26 (4): 179-187.

10.ROOM R, TURNER NE \& IALOMITEANU A - Community effects of the opening of the Niagara Casino. Addiction, 1999; 94 (10), 1449-1466.

11.TAVARES H, ZILBERMAN ML, BEITES $F$ et al. - Gender differences in gambling progression. J Gambling Stud (no prelo).

12.SOMMERS I - Pathological gambling: estimating prevalence and group characteristics. Int J Addictions, 1988; 23: 477-490.

13.OTHSUKA K, BRUTON E, DELUCA L et al. - Sex differences in pathological gambling using gaming machines. Psychol Rep, 1997; 80: 1051-1057.

14.ROOM R - Gender roles and interactions in drinking and drug use. J Subst Abuse, 1996; 8, 227-239.

15.SHAFFER HJ - The most important unresolved issues in addictions: conceptual chaos. Subst Use and Misuse, 1997; 32 (11), 1573 1580 .

16.BLACK DW \& MOYER T - Clinical features and psychiatric comorbidity of subjects with pathological gambling behaviour. Psych Serv, 1998; 49 (11): 1434-1439.

17.STEEL Z \& BLASZCZYNSKI A - Impulsivity, personality disorders and pathological gambling severity. Addiction, 1998; 93(6), 895-905.

18.ETTORRE B - Women and substance use/abuse: towards a feminist perspective or how to make a dust fly. Women's Stud Int Forum, 1989; 12: 593-602.

19.AMERICAN Psychiatric Association - Diagnostic and Statistical Manual of Mental Disorders. 4th ed. Washington, DC, 1994.

20.MARK ME \& LESIEUR HR - A feminist critique of problem gambling research. Br J Addiction, 1992; 87: 549-565.
21.LESIEUR HR - The Chase. Rochester, Schenkman Books, 1984.

22.BLUME SB \& LESIEUR HR - Characteristics of pathological gamblers identified among patients on psychiatric admissions service. Hosp Community Psychiatry, 1990; 41 (9): 1009. 1012 .

23.BLAND RC, NEWMAN SC, ORN H \& STEBELSKY G Epidemiology of pathological gambling in Edmonton. Can J Psychiatry, 1993; 38:108-112.

24.COVENTRY KR \& CONSTABLE B - Physiological arousal and sensation-seeking in female fruit machine gamblers. Addiction, 1999; 94 (3): 425-4320.

25.VOLBERG RA \& STEADMAN HJ - Refining prevalence estimates of pathological gambling. Am J Psychiatry, 1988; 145: 808814.

26.LEGARDA JJ, BABIO R \& ABREU JM - Prevalence estimates of pathological gambling in Seville (Spain). Br J Addiction, 1992; 87: $767-770$

27.COMAN GJ, BURROWS GD \& EVANS BJ - Stress and anxiety as factors in the onset of problem gambling: implications for treatment. Stress Medicine, 1997; 13: 235- 244.

28.LADOUCEUR R, DUBÉ D \& BUJOLD A - Prevalence of pathological gambling and related problems among college students in the Quebec metropolitan area. Can J Psychiatry, 1994; 39 (5): 289-293.

29.LESIEUR HR, CROSS J, FRANK M et al. - Gambling and pathological gambling among university students. Addict Behav, 1991; 16: 517-527.

30.STRACHAN ML \& CUSTER RL - Female compulsive gamblers in Las Vegas- In: EADINGTON WR \& CORNELIUS JA (Eds) - Gambling Behaviour and Problem Gambling. Reno, NV, Institute for the Study of Gambling and Commercial Gaming, 1993. p. $235-238$

31.ROSENTHAL RJ - Pathological gambling. Psychiatric Ann, 1992; 22: $72-78$

32.VOLBERG $\mathrm{R}$ - The prevalence and demographics of pathological gamblers: implications for public health. Am J Pub Health, 1994; 84: 237-241.

33.LISANSKY ES - Alcoholism in women: social and psychological concomitants. Q J Stud Alcohol, 1957; 18: 588-623.

34.PIAZZA, NJ, VRBKA, JL \& YEAGER, RD - Telescoping of alcoholism in women alcoholics. Int J Addictions, 1989; 24: 19-28.

35.ANGLIN MD, HSER YI \& MCGLOTHLIN WH - Sex differences in addict careers, II. Becoming addicted. Am J Drug Alcohol Abuse, 1987; 13: 59-71.

36.BLANKFIELD A - Female alcoholics. II. The expression of alcoholism in relationship to gender and age. Acta Psychiatr Scand, 1990; 81: 448-452. 
37.QUINBY PM \& GRAHAM AV - Substance abuse among women. Prim Care, 1993; 20: 131-140.

38.HOCHGRAF PB, ZILBERMAN ML \& ANDRADE AG - Women alcoholics: social, demographic and clinical characteristics in a Brazilian sample. Alc Alcohol, 1995; 30: 427-432.

39.SCHUKITT MA, ANTHENELLI RM, BUCHOLZ KK et al. - The time course of development of alcohol-related problems in men and women. J Stud Alcohol 1995; 56: 218-225.

40.SCHUKITT MA, DAEPPEN JB, TIPP JE et al. - The clinical course of alcohol-related problems in alcohol dependent and nonalcohol dependent drinking women and men. J Stud Alcohol 1998; 59 (5): 581-591.

41.LEWIS CE, BUCOLZ K, SPITZNAGEL E et al. - Effects of gender and comorbidity on problem drinking in a community sample. Alcohol: Clin Exp Res 1996; 20: 466-476.

42.RANDALL CL, ROBERTS JS, DEL BOCA FK et al. - Telescoping of landmark events associated with drinking: a gender comparison. J Stud Alcohol 1999; 60 (2): 252-260.

43.BECOÑA E, LORENZO MDC \& FUENTES MJ - Pathological gambling and depression. Psychol Rep 1996; 78: 635-640.

44.CROCKFORD DN \& EL-GUEBALY N - Psychiatric comorbidity in pathological gambling: a critical review. Can J Psychiatry 1998; 43: 43-50.

45.BRADY KT \& RANDALL CL - Gender differences in substance use disorders. Psych Clin North Am 1999; 22 (2): 241-52.

46.EISEN AS, LIN N, LYONS MJ et al. - Familial influences on gambling behavior: an analysis of 3,359 twin pairs. Addiction 1998; 93: 1375-84.

47.SHARPE L, TARRIER N, SCHOTTE D et al. - The role of autonomic arousal in problem gambling. Addiction 1995; 90: $1529-1540$

48.MORAN E - Gambling as a form of dependence. Br J Addiction 1970; 64: 419-428.

49.LESIEUR HR \& BLUME SB - Pathological gambling, eating disorders and the psychoactive substance use disorders. J Addictive Disorders 1993; 12: 89-102.

50.BLUME S - Pathological gambling: an addiction to an altered psychological state. Br Med J 1995; 311: 522-523.

51.SLUTSKE WS, EISEN S, TRUE WR et al. - Common genetic vulnerability for pathological gambling and alcohol dependence in men. Arch Gen Psychiatry 2000; 57: 666-673.

52.PEREZ DE CASTRO I, IBAÑEZ A, TORRES P et al. - Genetic association study between pathological gambling and a functional DNA polymorphism at the D4 receptor gene. Pharmacogenetics 1997; 7: 345-8.

53.COMINGS DE - The molecular genetics of pathological gambling. CNS Spectrums- Int J Neuropsychiatric Med 1998; 3 (6): 20-37.
54.IBAÑEZ A, PEREZ DE CASTRO I, FERNANDEZ-PIQUERAS J et al. - Pathological gambling and DNA polymorphic markers at MAO-A and MAO-B genes. Mol Psychiatry 2000; 5: 105109 .

55.VUKOV M, BABA-MILKIC $\mathrm{N}$ et al. - Personality dimensions of opiate addicts. Acta Psychiatr Scand 1995; 91: 103-107.

56.MESZAROS K, WILLINGER U, FISCHER G et al. - The tridimensional personality model: influencing variables in a sample of detoxified alcohol dependents. Compr Psychiatry 1996; 37: 109-14.

57.ROY A, CUSTER R, LORENZ V et al. - Personality factors and pathological gambling. Acta Psychiatr Scand 1989; 80: 3739.

58.EYSENCK H \& EYSENCK S - Manual of the Eysenck personality Questionnaire. London, Hodder and Stoughton, 1980.

59.BLASZCZYNSKI A, BUHRICH N MC \& CONAGHY N Pathological gamblers, heroin addicts and controls compared on EPQ “Addiction Scale”. Br J Addiction 1979; 80: 315-319.

60.EYSENCK SBG \& EYSENCK HJ - The place of impulsiveness in a dimensional system of personality description. Br J Clin Psychol 1977; 16: 57-68.

61.MENDLOWICZ MV, GIRARDIN JL, CHRISTIAN GILLIN J et al. - Sociodemographic predictors of temperament and character. J Psychiatric Res 2000; 34: 221-226.

62.CLONINGER CR, SVRAKIC DM \& PRZYBECK TR - A psychobiological model of temperament and character. Arch Gen Psychiatry 1993; 50: 975-990.

63.CLONINGER CR, PRYZBECK TR \& SVRAKIC DM et al. - The temperament and character inventory (TCI). A guide to its development and use- St Louis, MO. Washington University, Center for Psychobiology of Personality, 1994.

64.BRÄNDSTRÖM S, SCHLETTE P, PRYZBECK TR et al. - Swedish normative data on personality using the temperament and character inventory. Compr Psychiatry 998; 39(3), 122-128.

65.TAKEUCHI M, YOSHINO A, KATO M et al. - Reliability and validity of the Japanese version of the Tridimensional Personality Questionnaire among university students. Compr Psychiatry 1993; 34: 273-9.

66.TANAKA E, SAKAMOTO S, KIJIMA N et al. - Different personalities between depression and anxiety. J Clin Psychology 1998; 54: 1043-51.

67.MESZAROS K, LENZINGER E, HORNIK K et al. - The tridimensional personality questionnaire as a predictor of relapse in detoxified alcohol dependents. Alcoholism: Clin Exp Res 1999; 23 (3): 483-486.

68.POMERLEAU CS, POMERLEAU OF, FLESSLAND KA et al. Relationship of Tridimensional Personality Questionnaire scores and smoking variables in female and male smokers. J Subst Abuse 1992; 4: 143-154. 
69.ADEBAYO B - Gambling behaviour of students in grades 7 and 8 in Alberta, Canada. J Sch Health 1998; 68: 7-11.

70.DELFABBRO PH \& WINEFIELD AH - Predictors of irrational thinking in regular slot machines gamblers. Am J Psychol 2000; 134: 117-28.

71.REGIER DA, MYERS JK, KRAMER M et al. - The NIMH epidemiological catchment area program: historical context, major objectives, and study population characteristics. Arch Gen Psychiatry 1984; 45: 934-941.
72.CADORET RJ, YATES WR, TROUGHTON E et al. - Adoption study demonstrating two genetic pathways to drug abuse. Arch Gen Psychiatry, 1995; 52(1), 42-52.

73.CLONINGER CR - Assessment of the impulsive-compulsive spectrum of behavior by the seven-factor model of temperament and character. In: OLDHAM JM, HOLLANDER E \& SKODOL AE (Eds.). - Impulsivity and Compulsivity. Washington, DC, American Psychiatric Press, 1996. p. 59-95.

Received for publication on August 13, 2001. 